\title{
Experimental evidence of chemical deterrence against multiple herbivores in the seagrass Posidonia oceanica
}

\author{
Adriana Vergés ${ }^{1, *}$, Mikel A. Becerro ${ }^{1}$, Teresa Alcoverro ${ }^{1}$, Javier Romero ${ }^{2}$ \\ ${ }^{1}$ Centre d'Estudis Avançats de Blanes, CSIC, Accés a la Cala Sant Francesc, 14, 17300 Blanes, Girona, Spain \\ ${ }^{2}$ Departament d'Ecologia, Universitat de Barcelona, Avinguda Diagonal 645, 08028 Barcelona, Spain
}

\begin{abstract}
There is increasing evidence of the importance of herbivory in seagrass communities, but the factors that regulate seagrass-herbivore interactions remain largely unknown. Many terrestrial plants and marine algae chemically deter herbivores using secondary metabolites, yet their incidence and role on seagrasses have received little attention. Posidonia oceanica, the dominant seagrass in the Mediterranean Sea, suffers a high level of herbivory and produces phenolics, a type of compounds known to deter feeding in algae and terrestrial plants. We have experimentally quantified the chemical deterrence of $P$. oceanica against 3 types of sympatric consumers by comparing feeding on palatable agar-based foods containing aqueous and organic extracts of $P$. oceanica at natural concentrations with that on appropriate controls. The effect of plant chemistry was measured on the feeding of the sea urchins Spharechinus granularis, Paracentrotus lividus and Arbacia lixula, the mesograzer gastropod Cerithium vulgatum, and the general fish assemblage inhabiting $P$. oceanica meadows. Since these 5 experiments were run independently, we used meta-analysis to test the overall hypothesis that $P$. oceanica is chemically defended against multiple consumers and to compare the magnitude of their inhibition. Our results clearly showed that the seagrass extracts significantly deterred feeding, although inhibition varied between consumers. S. granularis was the most deterred organism, while the mesograzer $C$. vulgatum was the only species unaffected by $P$. oceanica extracts. These results represent the first experimental evidence for seagrass chemical deterrence against a range of consumers, and emphasise the potential importance of chemically mediated interactions between seagrass and herbivores.
\end{abstract}

KEY WORDS: Herbivory · Chemical defence · Seagrasses · Macrophyte · Mediterranean Sea

\section{INTRODUCTION}

A paradigm shift is clearly underway regarding the importance of herbivory on marine vascular plants. The concept that direct consumption of living seagrass tissues is uncommon and unimportant has prevailed until very recently (e.g. Cebrian 2002), but studies compiled over the last 2 decades demonstrate that present-day grazing of seagrass biomass can be large and is of central importance in regulating the dynamics of seagrass meadows (see review by Heck \& Valentine 2006 and references therein). Despite this, we know little about the mechanisms that regulate seagrassherbivore interactions, such as plant defences and how these influence the feeding behaviour of consumers.

Terrestrial plants, freshwater macrophytes and marine algae chemically deter herbivores using a wide range of secondary metabolites (Bennett \& Wallsgrove 1994, Pohnert 2004, Prusak et al. 2005). Despite the presence of some of these chemical compounds in seagrasses, very little consideration has been given to their potential role as feeding deterrents. In particular, phenolic compounds with well-known defensive properties in both terrestrial plants and seaweeds (Bennett 
\& Wallsgrove 1994, Amsler \& Fairhead 2006) are also widely abundant in seagrasses (Zapata \& McMillan 1979), but their function in these marine plants remains largely uninvestigated. Moreover, there is experimental evidence of the existence of chemical defences in some seagrasses. Crude extracts from the tropical seagrass Enhalus acoroides have been found to deter feeding by several species of fish (Paul et al. 1990, Meyer et al. 1994), and extracts from young Zostera marina leaves have been found to inhibit amphipod grazing (Harrison 1982). These results (1 type of consumer and 1 seagrass species in each case) suggest the defensive value of the plant chemical composition, but cannot be generalised, as the defensive value of the chemical composition of a given plant species is a specific function of both the secondary metabolites present and the herbivore species attacking the plant, and compounds that deter feeding in 1 consumer may have no effect on another. Therefore, in order to understand the general significance of chemically mediated interactions between seagrasses and their consumers we first need to assess the responses of multiple individual herbivores to the secondary metabolites of sympatric seagrass species.

In the present study, we attempted a step forward in that direction, by quantifying the chemical deterrence of Posidonia oceanica against 3 types of consumers. $P$. oceanica is the dominant seagrass in the Mediterranean Sea, where it forms extensive and highly productive meadows that are considered endangered key ecosystems (Boudouresque et al. 1989). A recent study demonstrates that herbivores can consume $>55 \%$ of the annual above ground primary production in shallow meadows (Prado et al. 2007), which constitutes a significant ecological impact that might be selecting for macrophyte defences, as in terrestrial and other marine systems (Bennett \& Wallsgrove 1994, Pohnert 2004). Moreover, P. oceanica is known to produce a wide variety of phenolic compounds (e.g. Agostini et al. 1998), which are enclosed in distinctive tanniferous cells (Pellegrini \& Pellegrini 1993). These highly specialised cells are common in vascular land plants and in some seagrasses, but interestingly they are absent from all other species in the genus Posidonia (Kuo \& McComb 1989).

The plant apparency model states that plants highly apparent to herbivores should invest heavily in defences that are generalised and effective against a broad range of herbivores, whereas unapparent plants invest in more toxic compounds that are poisonous at lower concentrations (Feeney 1976). Posidonia oceanica is a large and slow-growing species that dominates a climax community and, as such, is a highly apparent plant to herbivores. We therefore hypothesised that $P$. oceanica is chemically defended by generalised com- pounds that are deterrent to most herbivores. To test this hypothesis, we contrasted feeding on palatable agar-based foods containing polar and non-polar extracts of $P$. oceanica at natural concentrations with that on appropriate controls against a range of herbivores. In particular, we experimentally quantified and compared the effect of plant chemistry on the feeding of the sea urchins Spharechinus granularis, Paracentrotus lividus and Arbacia lixula, the mesograzer gastropod Cerithium vulgatum and the natural fish assemblage inhabiting $P$. oceanica meadows. We used the statistical technique of meta-analysis to quantitatively combine and compare the results from the individual deterrence experiments.

\section{MATERIALS AND METHODS}

Study organisms. Posidonia oceanica (L.) Delile is the dominant seagrass in the Mediterranean Sea. This magnoliophyte loses ca. $57 \%$ of its annual leaf production to herbivory. The 2 main consumers of $P$. oceanica are the edible sea urchin Paracentrotus lividus Lamarck and the sparid fish Sarpa salpa Linnaeus (Boudouresque \& Verlaque 2001, Prado et al. 2007). P. oceanica shoots were sampled in 3 different shallow meadows ( 3 to $8 \mathrm{~m}$, i.e. the range of maximum herbivore activity) in the western Mediterranean (NE Spain: Port-Lligat, $42^{\circ} 17.5^{\prime} \mathrm{N}, 3^{\circ} 17.2^{\prime} \mathrm{E}$; Fenals, $41^{\circ} 41.4^{\prime} \mathrm{N}$, $2^{\circ} 49.7^{\prime} \mathrm{E}_{\text {; }}$ Sa Nitja, $33^{\circ} 54^{\prime} \mathrm{N}, 5^{\circ} 25^{\prime} \mathrm{E}$ ) and in different seasons (from September 2003 to July 2004). The concentrations of some secondary metabolites, such as phenolics, are known to vary both seasonally and geographically (Agostini et al. 1998, Dumay et al. 2004). Consequently, all the material from different sites and times was pooled to compensate for differences in concentrations of secondary metabolites due to intraspecific variation. Fresh shoots were transported to the laboratory in aerated seawater containers, frozen and stored at $-80^{\circ} \mathrm{C}$. Samples were freeze-dried and cut into small pieces $\left(<1 \mathrm{~cm}^{2}\right)$ prior to chemical extractions.

We tested the palatability of Posidonia oceanica extracts against a range of herbivores, including the 3 most abundant echinoids on the Mediterranean coast and the fish community found in shallow seagrass meadows, i.e. the 2 main groups of macroherbivores in the NW Mediterranean (Hereu 2006). Additionally, we also tested for seagrass chemical deterrence against a gastropod mesograzer. The objective of this study was to determine whether $P$. oceanica is chemically defended against consumers. The fact that a particular herbivore does not feed on $P$. oceanica was not considered evidence that it is chemically deterred by this plant, as other mechanisms of defence or indeed many other physiological and/or ecological characteristics of 
both the consumer and the plant could be mediating or preventing that particular interaction. Thus, we deliberately tested for chemical deterrence against both herbivores that are known to feed on seagrass leaves and some that do not.

The edible sea urchin Paracentrotus lividus Lamarck is the most abundant urchin in the north-western Mediterranean and a critically important herbivore, as well as being one of the main consumers of Posidonia oceanica (Boudouresque \& Verlaque 2001 and references therein). Arbacia lixula (L.) is commonly found on hard substrata dominated by photophylic algal communities in shallow subtidal habitats. It is the second most abundant urchin in the NW Mediterranean, but is never present in P. oceanica meadows (Palacín et al. 1998). The purple sea urchin Sphaerechinus granularis Lamarck is the third most abundant urchin in the NW Mediterranean, and is typically found on deeper substrata composed of calcareous algae or coarser shell debris covered with macrophytes (Ballesteros 2006). S. granularis is present in low densities in $P$. oceanica meadows, and, although it is not known to feed on the standing leaves, it can consume fallen ones, scales and rhizomes (in Guillou et al. 2002). The gastropod Cerithium vulgatum Bruguière is a common mesograzer found in shallow sedimentary substrata and in rocky bottoms dominated by photophilic algae (Koutsoubas et al. 2000). C. vulgatum can be found in $P$. oceanica meadows, but is not known to feed on this seagrass. Deterrence against fish was tested in the field at a shallow $P$. oceanica meadow on the western side of the Medes Islands Marine Reserve $\left(42^{\circ} 1.8^{\prime} \mathrm{N}\right.$, $\left.3^{\circ} 13.3^{\prime} \mathrm{E}\right)$, where fish densities are particularly high and herbivores contribute over half of the total biomass, with the families Labridae, Sparidae, Serranidae and Scorpaenidae accounting for up to $50-70 \%$ of the total fish biomass (Macpherson et al. 2002).

For all aquarium bioassays, herbivores were collected from their respective habitats: Arbacia lixula individuals were collected from shallow rocky walls, Sphaerechinus granularis individuals were collected from the coralligenous habitat, Cerithium vulgatum individuals were collected from shallow rocky habitats dominated by photophylic algae and Paracentrotus lividus individuals were collected from Posidonia oceanica meadows. Animals were transported in aerated seawater tanks to the Aquarium de Barcelona or CEAB-CSIC aquarium facilities. In order to allow acclimatisation to aquarium conditions, during at least $2 \mathrm{~d}$ before conducting the assays all animals were fed fresh samples of the sympatric chlorophyte Ulva sp., a palatable alga that was readily eaten by all consumers and has no known deterrents. All assays were performed during the summer months, when herbivore activity peaks in the Mediterranean Sea (Tomas et al. 2005).
Chemical extraction procedure. Plant extracts were obtained from a bulk sample of Posidonia oceanica shoots made up of equal amounts of freeze-dried leaf blades from each time and location. We performed 2 separate extractions, one with non-polar solvents to extract lipophilic metabolites and the other with polar solvents to extract hydrophilic metabolites such as phenolics. The 2 extracts were later combined in the artificial foods. The bulk sample (63.8 g dry wt) was first extracted 3 times in $900 \mathrm{ml} \mathrm{1:1}$ ethyl acetate/ methanol to obtain the lipophilic secondary metabolites. For each extraction, the sample was sonicated for $10 \mathrm{~min}$ and soaked in solvent for $2 \mathrm{~h}$, except during the last extraction, when samples were soaked for $12 \mathrm{~h}$. The resulting non-polar extracts were combined and dried using rotary evaporation, and weighed to obtain the lipophilic crude extract yield. To extract water-soluble metabolites, the sample was further extracted 3 times in $900 \mathrm{ml}$ 1:1 distilled water/ethanol in an identical manner. The resulting crude extracts were also combined and dried using rotary evaporation, and weighed to obtain the polar crude extract yield.

Bioassay procedure. To quantify the deterrent properties of Posidonia oceanica, we conducted feeding preference assays in which herbivores were offered a choice of palatable agar-based foods containing seagrass extracts against control foods lacking these extracts, using methods outlined in Hay et al. (1998). For each experiment, polar and lipophilic seagrass extracts were combined and incorporated at natural concentrations (26 and $7.5 \%$, respectively) into artificial diets.

Feeding assays with the 3 urchins and with the gastropod were performed at the facilities of the Aquàrium de Barcelona and the CEAB-CSIC, and were set up in an identical manner using 1 experimental cage per individual herbivore. Lipophilic extracts were dissolved in $2 \mathrm{ml}$ of diethyl ether, and incorporated into the artificial diets by mixing the solution into $1.2 \mathrm{~g}$ of ground Ulva sp. and waiting for the solvent to evaporate. The resulting Ulva powder, coated evenly with lipophilic extract, was dissolved in $2 \mathrm{ml}$ of distilled water containing the polar extracts. We dissolved $1.2 \mathrm{~g}$ of agar in $28 \mathrm{ml}$ of distilled water and brought the solution to the boiling point. In order to avoid any breakdown of secondary metabolites due to high temperatures, we waited until the agar solution had cooled to about $<50^{\circ} \mathrm{C}$, and then added the solution containing both the ground Ulva and the extracts. This mixture was poured into an acrylic mould beneath which lay a thin plastic $2 \mathrm{~mm}$ window screen mesh. When the mixture solidified it adhered to the mesh, forming a thin strip. Control foods were prepared in an identical manner, but the ground Ulva was suspended in $2 \mathrm{ml}$ of diethyl ether and in $2 \mathrm{ml}$ of 
distilled water containing no extracts. Control and treatment strips were of identical shape and size, and were attached to the bottom of the individual experimental cages. Each herbivore was offered a choice between a treatment and a control agar strip ( $\mathrm{n}=20$ for each herbivore species), and consumption was measured as the number of mesh squares completely cleared of food. Additional control cages $(n=5)$ were set up with agar strips and no herbivores. The shape of the strips and the number of squares per strip in these control cages remained unchanged throughout the experiments. Since the artificial foods were immersed in seawater during the assays, some leaching of defensive compounds may have occurred, particularly of the most hydrophilic metabolites. In order to minimise potential false-negative results due to feeding after leaching of defensive compounds occurs, the assay ended when roughly half of the artificial foods were eaten or after a maximum of $48 \mathrm{~h}$.

Feeding assays with the fish community consisted of a field preference experiment where the fish were offered artificial food cubes with or without the seagrass extracts. Initial comparisons using different types of artificial foods demonstrated that ground fish food pellets (ProAqua Nutrición SA) and a mixture of 1:1 agar/carrageenan was the most palatable diet. Lipophilic extracts were dissolved in $2 \mathrm{ml}$ of diethyl ether, mixed with $1.25 \mathrm{~g}$ of ground fish food pellets until the solvent evaporated and subsequently dissolved in $2 \mathrm{ml}$ of distilled water containing the polar extracts. We dissolved $0.63 \mathrm{~g}$ of agar/carrageenan mixture (1:1) onto $20 \mathrm{ml}$ of distilled water and brought the solution to boiling the point. Once the agar solution had cooled down, we added the water containing the ground fish food and the extracts. This mixture was poured into $1 \mathrm{~cm}^{3}$ moulds containing a rubber O-ring. Once the mixture solidified, the resulting cubes were attached to ropes using safety pins fastened through the O-ring. Control foods were prepared in an identical manner, but both the diethyl ether and the water solutions contained no extracts. Each experimental rope was approximately $50 \mathrm{~cm}$ long and was fixed to the seafloor using a tent peg attached to its lower end, and maintained upright by a piece of buoyant foam at the upper end. Each rope had either 4 control or 4 treatment cubes (containing plant extracts), and control and treatment ropes were placed in pairs, each replicate pair at least $5 \mathrm{~m}$ apart from each other. All replicate pairs $(n=20)$ were placed in sandy patches within the seagrass meadow. Once the experimental units had been deployed, we checked for consumption of the agar cubes every 2 to $3 \mathrm{~h}$ until dusk, left them undisturbed overnight and collected the remaining cubes the next morning. Replicates were removed when roughly half of the cubes were eaten in any of the treatments. In those instances when cubes were only partially eaten, consumption was measured through visual approximation of the remaining agar volume in each cube to the nearest quarter $(1 / 4,2 / 4$, or $3 / 4$ cube consumed).

Statistical analyses. All data correspond to paired observations, since herbivores were simultaneously offered a choice between control or treatment foods. The Shapiro-Wilk test indicated a non-normal distribution of all bioassay results. Therefore, a nonparametric Wilcoxon signed-ranks paired test was used to compare feeding between the control and treatment foods using Systat Ver.10 software (SPSS Inc).

Since the 5 bioassays were run independently, we used meta-analysis to combine all results and to compare the magnitude of inhibition among herbivores. The statistical technique of meta-analysis provides a formal framework for the quantitative synthesis of the results of independent studies. It transforms the outcomes of each study into a measure of the effect size under study, which here is feeding deterrence. We used Hedges' $d$ as the metric in our meta-analysis, which corresponds to the differences in consumption between treatment and control means weighted by the sample size and the pooled standard deviation (Hedges \& Olkin 1985). We used a fixed-effects model to estimate the mean effect size, which assumes that individuals from each species share a common true effect size (Gurevitch \& Hedges 2001). Since our source data did not follow a normal distribution and some of the assays had small sample sizes, we used non-parametric variances to estimate the mean effect size and the $95 \%$ confidence intervals (CI) for each species (Adams et al. 1997). For the mean effect size we used a bias-corrected bootstrap CI generated from 10000 iterations (Adams et al. 1997). Methods such as bootstrapping generate their own distributions and are thus free from the assumptions of normality, and CIs obtained through these methods are more conservative than parametric methods for meta-analysis (Adams et al. 1997). An effect size is considered significant if the CI does not include zero, and different species are considered to significantly differ from each other in their degree of deterrence if their CIs do not overlap. The meta-analysis was carried out using the MetaWin 2.0 statistical program (Rosenberg et al. 2000).

\section{RESULTS}

The crude extracts of Posidonia oceanica deterred feeding by all the herbivores tested (Fig. 1A to D), except the mesograzer Cerithium vulgatum, which showed no preference between the control and the 

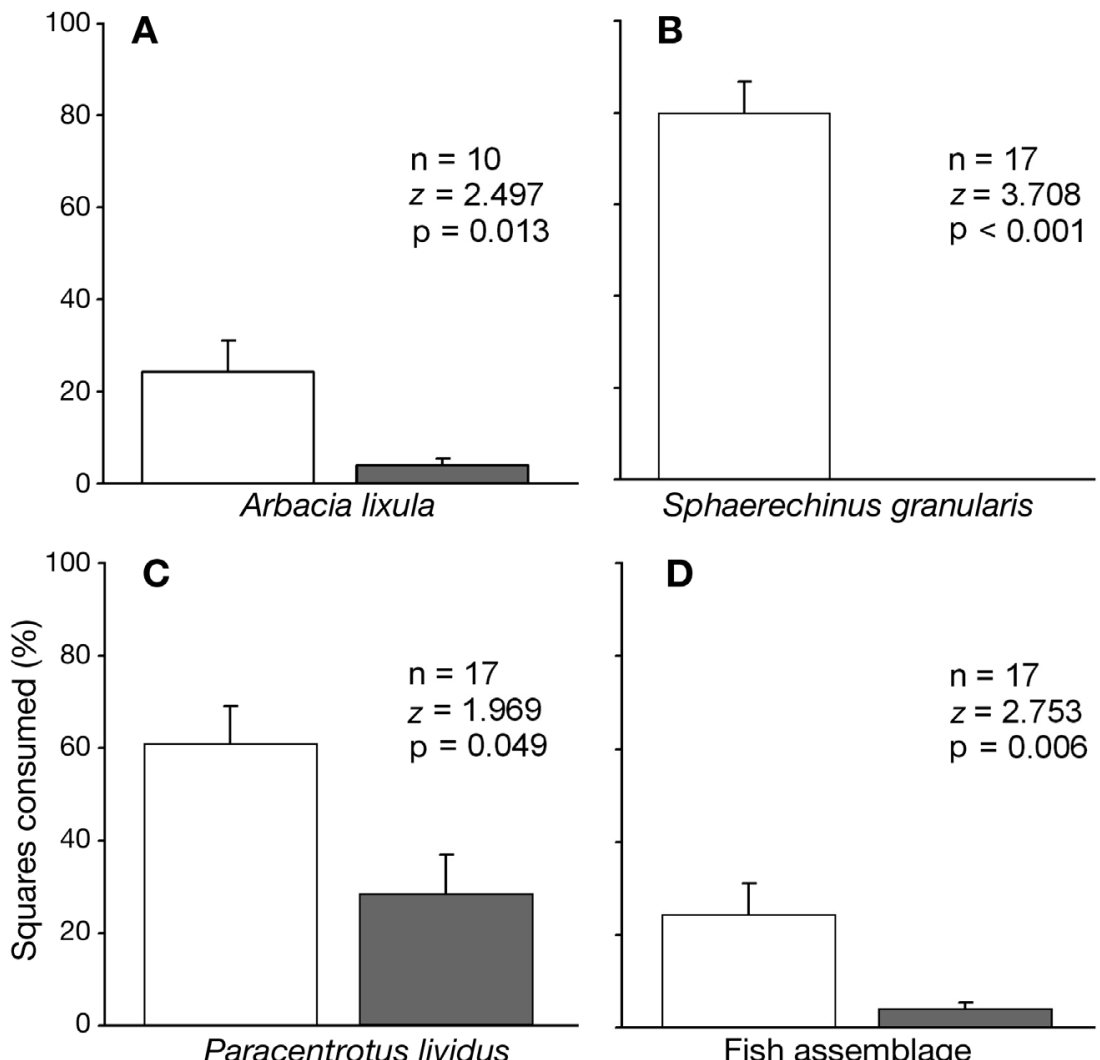

Paracentrotus lividus
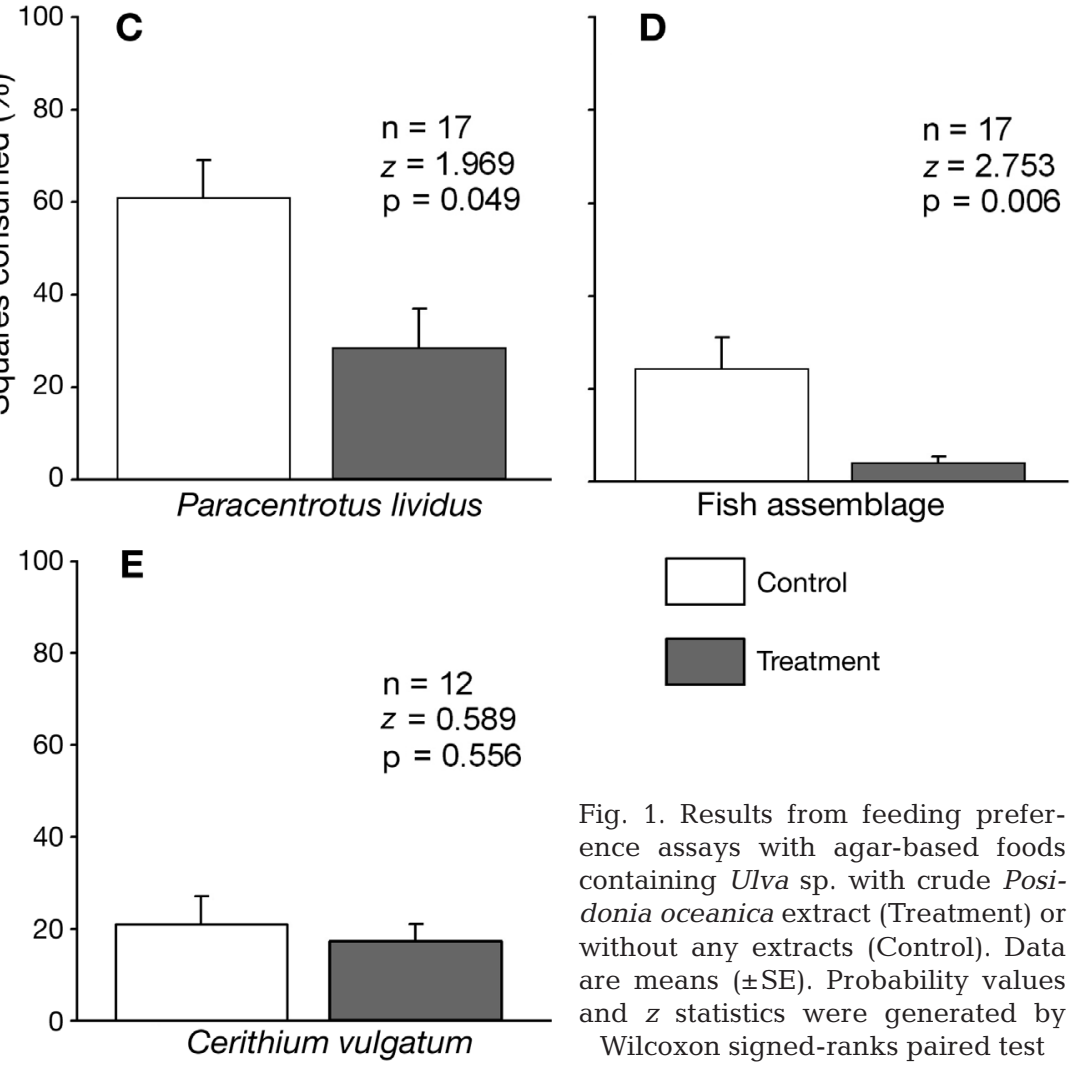

Fish assemblage

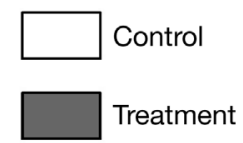

Fig. 1. Results from feeding preference assays with agar-based foods containing Ulva sp. with crude Posidonia oceanica extract (Treatment) or without any extracts (Control). Data are means $( \pm \mathrm{SE})$. Probability values and $z$ statistics were generated by Wilcoxon signed-ranks paired test

In the fixed-effects meta-analysis results, when the effect sizes from all the bioassays were analysed together, the grand mean effect size was negative (Fig. 2) and significantly different from zero. We found differences in the degree of deterrence of the different herbivores, as indicated by a significant between-species heterogeneity $(\mathrm{Qt}=58.538$; df $=4$; p < 0.0005). Sphaerechinus granularis was significantly more deterred by the Posidonia oceanica crude extracts than all other herbivores (Fig. 2). The urchins Paracentrotus lividus and Arbacia lixula, and the natural fish assemblage inhabiting $P$. oceanica meadows were equally deterred (Fig. 2). The gastropod Cerithium vulgatum was the only herbivore not deterred by the seagrass extracts, as the CI around the mean effect size includes zero (Fig. 2).

\section{DISCUSSION}

We found strong evidence that the temperate seagrass Posidonia oceanica is chemically defended against diverse herbivores, including 3 species of urchins and the fish assemblage inhabiting $P$. oceanica meadows. Only the mesograzer gastropod Cerithium vulgatum was undeterred by the plant's crude extracts. These results represent the first experimental evidence of seagrass chemical deterrence against a wide range of consumers, and emphasise the importance of chemically mediated trophic interactions in seagrass ecosystems.

treatment foods (Fig. 1E). Sphaerechinus granularis was the most deterred herbivore (Fig. 1B), and Arbacia lixula and Paracentrotus lividus were similarly deterred (Fig. 1A,C). The fish assemblage inhabiting the seagrass meadow was also effectively deterred by the plant's extracts (Fig. 1D). Even though we observed a few whole agar cubes completely eaten $(<10 \%)$, we found small fractions of agar food removed by small fish in the majority of the cubes, judging by the size of the bites. The fish species most commonly seen feeding on the cubes were Coris julis, Boops boops, Oblada melanura and various species of the genus Symphodus, as we observed in SCUBA diving inspections.
Herbivory in aquatic systems is 3 times higher than in terrestrial systems (Cyr \& Pace 1993), and seagrasses, in particular, can lose significant amounts of biomass to secondary producers (Heck \& Valentine 2006). Seagrasses might have selected for efficient chemical defences to lessen the impact of herbivores, as has been reported for both plankton and macroalgae (see review by Pohnert 2004) and for freshwater macrophytes (e.g. Prusak et al. 2005). However, only a handful of studies have directly evaluated the role of chemical defences in marine vascular plants. To the best of our knowledge, previously published studies include just 3 seagrass species that were tested for deterrence against 3 species of fish and an amphipod. 


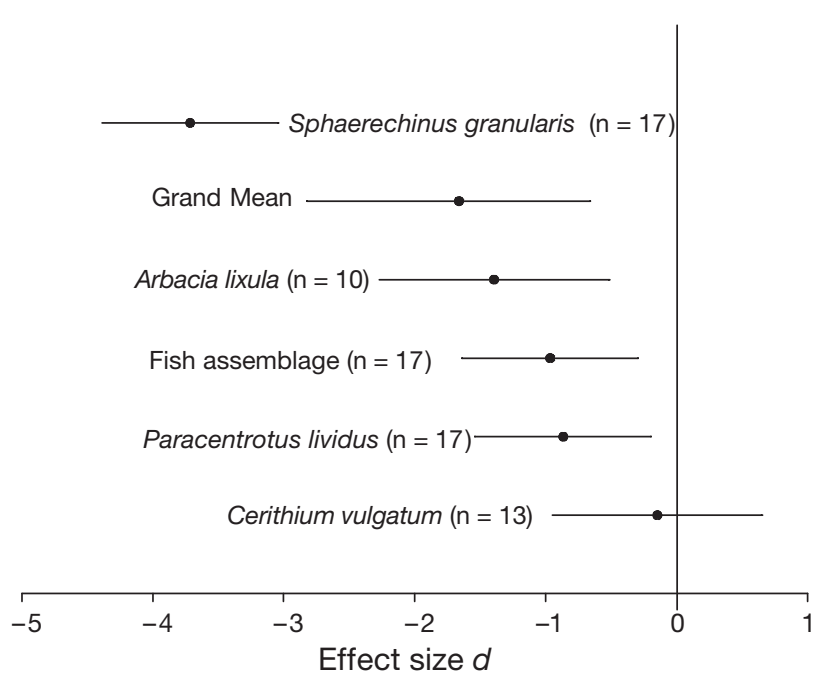

Fig. 2. Effect sizes and confidence intervals (CI) from the meta-analysis including all feeding assays. Effects are significantly different from zero if CIs do not overlap with zero $(\mathrm{p}<0.05)$. Individual species have $95 \%$ CIs generated using non-parametric variances. For the grand mean, we used a bias-corrected bootstrap CI generated from 10000 iterations

Including the results from our study, 3 out of the 4 marine vascular plants tested to date are chemically defended against sympatric herbivores. Enhalus acoroides and Zostera marina chemically deter herbivores (Harrison 1982, Meyer et al. 1994, Paul et al. 1990), as does Posidonia oceanica, whereas Halophila minor shows no deterrence (Paul et al. 1990). The chemically defended $P$. oceanica, E. acoroides and $Z$. marina are all dominant species with relatively slow growth rates (Hemminga \& Duarte 2000), whereas the palatable $H$. ovalis is an ephemeral pioneer species with a fast growth rate (Vermaat et al. 1995), which may rely on spatial and temporal escape to avoid being eaten. These results are in accordance with the plant apparency model, which predicts that long-lived dominant species that are 'bound to be found' by herbivores should be defended by generalised feeding deterrents that are effective against a broad range of herbivores (Feeney 1976).

The specific chemical compounds responsible for feeding deterrence have not been isolated in any of the seagrasses tested. Seagrasses are a rich source of phenolics (Zapata \& McMillan 1979), which are known to reduce palatability and increase toxicity to herbivores, both in terrestrial plants (e.g. Bennett \& Wallsgrove 1994) and in marine seaweeds (see review by Amsler \& Fairhead 2006). Phenolic compounds may therefore also act as feeding deterrents in these marine plants. Phenolic metabolites include a wide range of compounds with both primary and secondary functions. Besides serving as important structural components of cell walls, seagrass phenolics have also been hypothesised to play many other ecological roles other than herbivore deterrence. Seagrass phenolics are reported to act as metal chelators, thereby providing an internal detoxification mechanism against heavy metals (Agostini et al. 1998) and are considered key allelopathic agents (e.g. Dumay et al. 2004). Flavonoids are believed to protect these plants against UV radiation (e.g. Trocine et al. 1981). Additionally, accumulation of phenolics has been correlated with reduced microbial growth (e.g. Harrison 1982) and with the occurrence of pathogen infection (e.g. Steele et al. 2005 and references therein). Moreover, some authors have suggested that phenolics may be storage products when organic carbon is present in excess of that which can be metabolised, or as a result of changing patterns of carbon-based resource allocation (Steele et al. 2005). However, the only experimentally demonstrated ecological role of specific seagrass phenolics is that of chemical defence against fouling microorganisms (e.g. Jensen et al. 1998).

In our study, we found differences among herbivores in the degree of deterrence of Posidonia oceanica secondary metabolites. The urchin Sphaerechinus granularis was highly deterred, and showed the strongest response against the crude extracts from the plants. This urchin is most commonly found in deep substrata feeding on detritus, maerl, encrusting coralline algae and some macroalgae such as Laminaria digitata (Guillou et al. 2002 and references therein). S. granularis is present in low densities in meadows of $P$. oceanica and it feeds on low-phenolic content tissues such as dead leaves, scales and rhizomes (Campos-Villaca in Guillou et al. 2002).

The urchins Arbacia lixula and Paracentrotus lividus were equally deterred by the extracts of Posidonia oceanica. These 2 urchins share feeding behaviour, but partially differ in their habitat, since $A$. lixula is restricted to the shallower part of vertical walls (Bulleri et al. 1999) and is absent from seagrass meadows (Palacín et al. 1998). Our results show that chemical deterrence is at least one of the mechanisms preventing $A$. lixula from feeding on $P$. oceanica, thus contributing to explain the scarcity of this urchin in seagrass beds.

Contrarily, Paracentrotus lividus is common in meadows of Posidonia oceanica, and is one of the main consumers of the plant (Tomas et al. 2005), which may seem paradoxical given that it is chemically deterred by this plant. However, in decreasing order of preference $P$. lividus feeds on epiphyte-covered green leaves, brown dead leaf tips with epiphytes, apical tips of green leaves without epiphytes and, lastly, green leaf bases without epiphytes (Boudouresque \& Verlaque 2001 and references therein). This strong 
order of preference is inversely related to the concentration of phenolic compounds in these tissues (Agostini et al. 1998) and consistent with the chemical deterrency found in our study. Nevertheless, a recent study has found that secondary metabolites of this seagrass act in conjunction with critical structural components to deter this urchin (Vergés et al. 2007).

The crude extracts of Posidonia oceanica also deterred the fish assemblage inhabiting the seagrass meadows, which is consistent with few fish species feeding directly on this seagrass (Pinnegar \& Polunin 2000). In fact, the sparid fish Sarpa salpa is the only species that incorporates $P$. oceanica leaves as a main constituent of its diet, consuming $40 \%$ of the plant's above ground primary production (Prado et al. 2007). Our study does not allow us to draw any conclusions on the feeding behaviour of S. salpa; however, this fish species has a distinctly large bite size and SCUBA diving observations of the fish and the size of their bites indicate that only small-sized fish species were involved in our experiments.

The gastropod Cerithium vulgatum was the only organism tested that was not chemically deterred by Posidonia oceanica. This gastropod has soft chitineous teeth and weak buccal muscles that are effective in grazing microalgae and filamentous algae, but are of limited use for grazing tougher substrata (Steneck \& Watling 1982). The feeding apparatus of C. vulgatum is therefore not suited to feed on tough seagrass leaves, and structural mechanisms alone appear to fully defend $P$. oceanica against this particular grazer. Thus, out of all the herbivores tested, the only organism not chemically deterred by $P$. oceanica is the one that is physically unable to eat the plant itself, since all others are known to feed on comparable macrophytes of at least equivalent toughness and similar morphology (i.e. 'leathery macrophytes' sensu Steneck \& Watling 1982).

Our results emphasise the importance of chemically mediated interactions between herbivores and the dominant Mediterranean seagrass, Posidonia oceanica. These interactions have important ecological and evolutionary implications (Paul et al. 2001) that we are only starting to uncover in marine vascular plants. Seagrass meadows are recognised as key ecosystems that are declining world-wide due to both anthropogenic and natural disturbances, and the associated loss of the ecological functions provided by these systems is a cause of mounting concern (e.g. Duarte 2002). Since overgrazing is a significant cause of seagrass decline that has been reported repeatedly during the last $50 \mathrm{yr}$ (e.g. Valentine \& Duffy 2006 and references therein), understanding the processes that influence seagrass herbivory is also critical to effectively manage these valuable natural resources.
Acknowledgements. We thank the Aquarium de Barcelona for the use of their aquarium facilities, and, in particular, P. Bultó, T. Plaça and F. Inglada for their support throughout this study. We especially appreciate the help given by E. Ballesteros and P. Renom in finding and collecting Sphaerechinus granularis individuals, D. Costalago and E. Gacia for collection of Cerithium vulgatum specimens and G. Roca for his assistance underwater and in setting up the aquarium experiments. The manuscript benefited from the input of 2 anonymous reviewers. This work was supported by Grant REN2002-04020-C02 from the Spanish Ministry of Science and Education.

\section{LITERATURE CITED}

Adams DC, Gurevitch J, Rosenberg MS (1997) Resampling tests for meta-analysis of ecological data. Ecology 78: $1277-1283$

Agostini S, Desjobert J, Pergent G (1998) Distribution of phenolic compounds in the seagrass Posidonia oceanica. Phytochemistry 48:611-617

Amsler CD, Fairhead VA (2006) Defensive and sensory chemical ecology of brown algae. Adv Bot Res 43:1-91

Ballesteros E (2006) Mediterranean coralligenous assemblages: a synthesis of the present knowledge. Oceanogr Mar Biol Annu Rev 44:123-195

Bennett RN, Wallsgrove RM (1994) Secondary metabolites in plant defense mechanisms. New Phytol 127:617-633

Boudouresque C, Verlaque M (2001) Ecology of Paracentrotus lividus. In: Lawrence JM (ed) Edible sea urchins: biology and ecology. Elsevier Science, Amsterdam, p 177-216

Boudouresque C, Meinesz A, Fresi E, Gravez V (1989) International workshop on Posidonia beds. GIS Posidonie, Marseille

Bulleri F, Benedetti-Cecchi L, Cinelli F (1999) Grazing by the sea urchins Arbacia lixula L. and Paracentrotus lividus Lam. in the Northwest Mediterranean. J Exp Mar Biol Ecol 241:81-95

Cebrian J (2002) Variability and control of carbon consumption, export, and accumulation in marine communities. Limnol Oceanogr 47:11-22

Cyr H, Pace ML (1993) Magnitude and patterns of herbivory in aquatic and terrestrial ecosystems. Nature 361 : $148-150$

Duarte CM (2002) The future of seagrass meadows. Environ Conserv 29:192-206

Dumay O, Costa J, Desjobert J, Pergent G (2004) Variations in the concentration of phenolic compounds in the seagrass Posidonia oceanica under conditions of competition. Phytochemistry 65:3211-3220

Feeney P (1976) Plant apparency and chemical defense. In: Wallace J, Mansell R (eds) Recent advances in phytochemistry, Vol 10. Plenum Press, New York, p 1-40

Guillou M, Grall J, Connan S (2002) Can low sea urchin densities control macro-epiphytic biomass in a north-east Atlantic maerl bed ecosystem (Bay of Brest, Brittany, France)? J Mar Biol Assoc UK 82:867-876

Gurevitch J, Hedges L (2001) Meta-analysis: combining the results of independent experiments. In: Scheiner S, Gurevitch J (eds) Design and analysis of ecological experiments. Oxford University Press, Oxford

Harrison P (1982) Control of microbial growth and of amphipod grazing by water soluble compounds from leaves of Zostera marina. Mar Biol 67:225-230

Hay M, Stachowicz J, Cruz-Rivera E, Bullard S, Deal M, Lindquist N (1998) Bioassays with marine and freshwater 
organisms, Chapter 2. In: Haynes K, Millar J (eds) Methods in chemical ecology, Vol 2. Chapman \& Hall, Norwell

Heck KL, Valentine JF (2006) Plant-herbivore interactions in seagrass meadows. J Exp Mar Biol Ecol 330:420-436

Hedges L, Olkin I (1985) Statistical methods for meta-analysis. Academic Press, New York

Hemminga M, Duarte C (2000) Seagrass ecology. Cambridge University Press, Cambridge

Hereu B (2006) Depletion of palatable algae by sea urchins and fishes in a Mediterranean subtidal community. Mar Ecol Prog Ser 313:95-103

Jensen PR, Jenkins KM, Porter D, Fenical W (1998) Evidence that a new antibiotic flavone glycoside chemically defends the seagrass Thalassia testudinum against zoosporic fungi. Appl Environ Microbiol 64:1490-1496

Koutsoubas D, Arvanitidis C, Dounas C, Drummond L (2000) Community structure and dynamics of the molluscan fauna in a Mediterranean lagoon (Gialova lagoon, SW Greece). Belg J Zool 130:135-142

Kuo J, McComb A (1989) Seagrass taxonomy, structure and development. In: Larkum A, McComb A, Shepherd S (eds) Biology of seagrasses: a treatise on the biology of seagrasses with special reference to the Australian region. Elsevier, Amsterdam, p 6-67

Macpherson E, Gordoa A, Garcia-Rubies A (2002) Biomass size spectra in littoral fishes in protected and unprotected areas in the NW Mediterranean. Estuar Coast Shelf Sci 55: 777-788

Meyer KD, Paul VJ, Sanger HR, Nelson SG (1994) Effects of seaweed extracts and secondary metabolites on feeding by the herbivorous surgeonfish Naso lituratus. Coral Reefs 13:105-112

Palacín C, Turon X, Ballesteros M, Giribet G, Lopez S (1998) Stock evaluation of three littoral echinoid species on the Catalan coast (north-western Mediterranean). PSZN I: Mar Ecol 19:163-177

Paul VJ, Nelson SG, Sanger HR (1990) Feeding preferences of adult and juvenile rabbitfish Siganus argenteus in relation to chemical defenses of tropical seaweeds. Mar Ecol Prog Ser 60:23-34

Paul VJ, Cruz-Rivera E, Thacker RW (2001) Chemical mediation of macroalgal-herbivore interactions: ecological and evolutionary perspectives. In: McClintock J, Baker W (eds) Marine chemical ecology. CRC, Boca Raton, FL

Pellegrini L, Pellegrini M (1993) Ultrastructural differentiation

Editorial responsibility: Kenneth Heck (Contributing Editor), Dauphin Island, Alabama, USA of the tanniniferous cells in the marine phanerogam Posidonia oceanica (L) Delile. Bot Mar 36:179-187

Pinnegar JK, Polunin NVC (2000) Contributions of stableisotope data to elucidating food webs of Mediterranean rocky littoral fishes. Oecologia 122:399-409

Pohnert G (2004) Chemical defense strategies of marine organisms. Top Curr Chem 239 (Chemistry of pheromones and other semiochemicals I):179-219

Prado P, Tomas F, Alcoverro T, Romero J (2007) Extensive direct measurements of Posidonia oceanica defoliation confirm the importance of herbivory in temperate seagrass. Mar Ecol Prog Ser 340:63-71

Prusak AC, O'Neal J, Kubanek J (2005) Prevalence of chemical defenses among freshwater plants. J Chem Ecol 31: $1145-1160$

Rosenberg MS, Adams DC, Gurevitch J (2000) MetaWin: statistical software for meta-analysis. Sinauer Associates, Sunderland

Steele L, Caldwell M, Boettcher A, Arnold T (2005) Seagrass-pathogen interactions: 'pseudo-induction' of turtlegrass phenolics near wasting disease lesions. Mar Ecol Prog Ser 303:123-131

Steneck RS, Watling L (1982) Feeding capabilities and limitation of herbivorous mollusks - a functional-group approach. Mar Biol 68:299-319

Tomas F, Turon X, Romero J (2005) Seasonal and small-scale spatial variability of herbivory pressure on the temperate seagrass Posidonia oceanica. Mar Ecol Prog Ser 301:95-107

Trocine RP, Rice JD, Wells GN (1981) Inhibition of seagrass photosynthesis by ultraviolet-B radiation. Plant Physiol 68: 74-81

Valentine J, Duffy J (2006) The central role of grazing in seagrass ecosystems. In: Larkum A, Orth R, Duarte C (eds) Seagrasses: biology, ecology and conservation. Springer, Berlin, p 463-502

Vergés A, Becerro MA, Alcoverro T, Romero J (2007) Variation in multiple traits of vegetative and reproductive seagrass tissues influences plant-herbivore interactions. Oecologia 151(4):675-686

Vermaat JE, Agawin NSR, Duarte CM, Fortes MD, Marba N, Uri JS (1995) Meadow maintenance, growth and productivity of a mixed Philippine seagrass bed. Mar Ecol Prog Ser 124:215-225

Zapata O, McMillan C (1979) Phenolic-acids in seagrasses. Aquat Bot 7:307-317

Submitted: September 5, 2006; Accepted: January 10, 2007 Proofs received from author(s): July 18, 2007 